\title{
Investment Portfolio of Banks and Economic Growth in Nigeria: A Review from 1985 to 2015
}

\author{
Uduak B. Ubom ${ }^{1}$, Sunny Okon Akpan ${ }^{2}$ \\ ${ }^{1,2}$ Department of Banking \& Finance, Faculty of Business Administration, University of Uyo, Uyo \\ *Corresponding Author: Uduak B. Ubom, Department of Banking \& Finance, Faculty of Business \\ Administration, University of Uyo, Uyo, Email: udbernard@yahoo.com.
}

\begin{abstract}
In this study, the relationship between investment portfolio of banks and economic growth in Nigeria was examined. The work was designed to find out the structure and trend of bank investment portfolio in Nigeria and to establish the relationship between gross domestic product, unemployment rate, per capita income and bank investments in treasury bills, bonds and shares in Nigeria from 1985 to 2015. The desk research design was used and secondary data obtained from the Central Bank of Nigeria (CBN) Statistical Bulletin, publications of the National Bureau of Statistics (NBS) as well as internet sources, among others. The data collected were analyzed using the regression models and various test statistics including the $t$ statistic, f-ratio and Dublin Watson statistic. It is discovered that there exist significant relationship between the variables of economic growth and the variables of investment portfolio of banks in Nigeria. It was therefore concluded that although; there exist statistical significant relationship between the variables of economic growth and those of investment portfolio of banks in Nigeria, the real situation in the country is rather that of marginal and/or insignificant relationship. This is in view of the fact that even when there is an observed continuous increment in the total investment portfolio of banks, the level of economic growth in the country is rather abysmal. From the conclusions above, it was recommended, among others, that bank should restructure their investment portfolio with focus on long term securities to ensure increase in the maturity and the volume of funds made available to the borrower through such investments and the various investment portfolio adjustments by banks in reaction to monetary policy changes and interest rate movements in the country should be properly managed, timed and harnessed with the bank policies, objectives and economic growth aspiration and direction of the government.
\end{abstract}

Keywords: Investment portfolio, Portfolio mix, Economic growth, Shift ability theory and Profit maximization theory.

\section{INTRODUCTION}

Banks mobilize savings and allocate them to the various sectors of an economy to satisfy their consumption and investment needs. This is carried out through lending which involves granting of loans and advances and investment in securities (i.e. financial instruments). Hence, banks maintained two asset portfolios including loan and investment portfolios.

By granting loans to economy and investing in financial assets, the level of economic and business activities is increased. For instance, they promote business investments and stimulate the markets for factor inputs, commodities and services. Considering the influences of banks on business operations, markets and on the growth of the economy as a whole, banks are regarded as economic development and growth agents. They propel the economy by making funds available to facilitate business operations, expansions, stimulate the markets, and improve economic performance (Akani, Lucky \& Uzah, 2016) and (Akani \& Momodu, 2016).

However, it should be pointed out that the extent to which banks can contribute to economy is dependent on a good number of factors. For instance, Ubom, Michael \& Essien (2016) identified such factors to include absorption level of the economy and monetary policy issues. In this work, the portfolios of banks as a whole and investment portfolio in particular is identified and investigated upon as one of the prime factors affecting banking sector contributions to economic growth.

Investment portfolio of banks is the collection of financial instruments held by the banks at any point in time. The financial intermediaries purchase and hold securities of diverse forms for the purpose of 
earning income and as liquidity management strategy. Through the purchase of these instruments (from the governments and business enterprises), they make funds available to the issuers of the assets for use in funding long term investments and for other purposes. For instance, governments make use of the funds to provide infrastructure and other amenities in the economy as well as financing budget deficits. On the other hand, business enterprises require such funds to satisfy their working capital and long term investment needs.

The investment portfolios of banks are expected to be dominated by long term securities such as bonds and shares in order to support high volume of long term investments by the borrowers. Such high volume of long term investments in infrastructure and capital/industrial assets are required for economic development and growth (Anyanwu, 2010). In other words, the availability of long term funds as a result of appropriate mix of assets in investment portfolio of banks enable governments to increase the stock and quality of infrastructure and business firms to expand their asset base and operations in the economy. These tend to promote increase in output of goods and services, generate more employment opportunities, as well as increase in capacity utilization rate and improvement in per capita income among others. Improvements in these variables are the necessary ingredients of industrialization and economic growth as experienced in advanced countries of the world.

However, characteristically, investment portfolios of banks in Nigeria have been noted to be dominated by short term assets. These short term assets, by implication, make short term funds available to the borrowers (issuers of the instruments). The short term funds do not support long term investments both in the public and private sectors of the economy. As a result, it is observed that while the investment portfolios of banks increase on daily basis, the level of economic development and growth in the country is rather decreasing. Where it tends to increase, the rate of increment is very marginal or negligible and at times, transient. This, therefore, calls to question, the extent to which investment portfolios of banks have contributed to economic growth in Nigeria.

Interestingly, it is possible to observe that investment portfolios of the financial institutions are not properly aligned with economic development and growth focus and potentials of the economy as a whole. Although, there are many works on banking sector contributions to economic development and growth in developing countries as a whole and Nigeria in particular, such works fail to pay particular attention to the structural defects inherent in investment portfolio of banks as it affects economic growth in the country.

In line with the above notion, this work has been carried out to examine investment portfolio of banks and economic growth in Nigeria from 1985 to 2015. In particular, the article seeks to examine the structure and trend of investment portfolios of banks in Nigeria, identify the factors affecting investment portfolio of the financial institutions and to establish the relationship that exist between the investment portfolio of banks and economic growth in Nigeria from 1985 to 2015.

Following from above, the research questions below became pertinent:

i. What has been the structure and trend of investment portfolios of banks in Nigeria from 1985 to 2015 ?

ii. What are the factors affecting investment portfolios of banks in the country for the period stated above?

iii. What relationships exist between investment portfolio of banks and economic growth in Nigeria from 1985 to 2015 ?

This article is therefore designed to address the issues raised in these research questions.

\section{REVIEW OF LITERATURE}

\subsection{Conceptual Review}

\subsubsection{The Concept and Nature of Investment Portfolio}

Investment involves the purchase of assets, such as tangible and financial assets or instruments. These assets are held by the investors including household individuals, business firms and governments in the hope of realizing some forms of benefits in the future. The future is unknown and therefore, the investment made is exposed to risk (Ubom, 2010). That is, the risk of losing the capital and/or not realizing the benefits as expected.

Every investor therefore strives to select and hold securities with varying degrees of maturity risk and return potentials. These assets are held by the investors to satisfy their investment needs and to 
achieve their investment objectives. These objectives include ensuring safety to capital invested, stability of income and to maximize or optimize returns. The collection of the various financial assets held by an investor at any point in time is known as investment portfolio.

Banks as institutional investors purchase and hold these assets in order to earn income, maximize profits (Ngerebo \& Lucky, 2016) and also as liquidity management strategy. Usually, banks pursue two important objectives. These are maintenance of adequate liquidity level at all times and optimization of returns. The investment portfolio of banks should be consistent with these objectives (Ubom, 2009).

The asset mix of investment portfolios vary depending on the type of investors. For instance, riskaverse investors, such as civil servants, retirees, etc. will consider government securities in their investment portfolios more than corporate securities with high level of risk. The aggressive investors on the other hand would rather prefer the dominance of corporate securities with high risk in their investment portfolios. Such high risk assets are considered for their high return potentials.

The investment portfolio of banks in view of the nature of banking business, the operational objectives of banks as well as monetary policy stipulations are not the same with those of other institutional investors. The regulatory provisions specify the type of assets and the amount of funds as a fraction of shareholders funds or capital base banks should invest in financial instruments.

\subsubsection{Structure of Investment Portfolio of Banks}

Some of the major factors affecting bank investment portfolio structure are risk, regulatory provisions, asset base, income potentials and bank size, among others. Considering these factors, especially risk, banks select different assets to form their investment portfolios. As identified by Orabi (2012), investments vehicles open to banks are two broad groups. These are money market instruments (e.g. treasury bills, certificate of deposit, etc.), capital market instruments (e.g. bonds, preference shares, and common stock), structured notes and derivative securities.

The structure of investment portfolio of banks, in most cases, is designed to reflect interest rate movements in the economy (Bukue and Ubom, 2013). Interest rate is one of the monetary policy tools. When the movement of interest rate is favorable to banks in terms of earning more income, the banks will switch over to the direction of the investment vehicles with increasing interest rates and vice versa. However, this has posed a serious problem to banks in managing their investment portfolios, especially in Nigeria, where interest rate fluctuations is very wild.

The difficulty of managing an investment portfolio stems not only from the uncertainty in future interest-rate movements but from the conflicting uses of the portfolio. On the one hand, the portfolio is used to generate income, which argues for investing in the highest-yielding securities. On the other hand, the portfolio acts as a liquidity buffer, providing or absorbing funds for the rest of the bank, depending upon other demands for funds. Many banks manage their investment portfolio using a laddered maturity structure, in which the amount invested in each maturity is the same for all maturities up to some appropriate length. Orabi (2012).

Generally, the longer the ladder, the more risky the portfolio is considered. The advantages of a laddered portfolio are: no transaction costs or realized losses, since securities are always held to maturity rather than sold; generally high interest income, since the yield curve is usually rising with increasing maturity; no forecasting is needed and a relatively small percentage of the portfolio needs to be reinvested each year. Some banks, on the other hand, manage their portfolio using a barbell maturity structure, in which the maturities held are clustered at the short and long ends of the maturity spectrum, with little, if any, investment with intermediate maturities. The advantages of a barbell portfolio are usually stated in terms of being more efficient than a laddered portfolio. The securities on the long end provide relatively high interest income, as well as potential for capital gains in the event of falling interest rates, while the securities on the short end provide liquid assets to meet various demands for cash from the portfolio to satisfy bank needs (Bradley and Crane, 1975).

\subsubsection{Investment Portfolio of Banks and Economic Growth}

The purchase of financial assets by investors places financial resources or capital at the disposal of the issuers of the instruments for use in the production of goods and services and/or for provision of social services, amenities and infrastructures. Securities issued by the government provide the resources to the government to finance budget deficits and to provide for infrastructure such as road networks, communication facilities, hospitals, schools, health care facilities, etc. In the case of 
business firms, the securities are issued to raise funds for purchase of raw materials, recruitment of personnel, replacement of assets, research and development, diversification and expansion, among others.

Some activities, alongside the infrastructure and amenities provided by the government lead to improvement in business performance, increase employment opportunities, increase output of goods and services, price stability, improve social welfare, among other. It should be observed that the structure of bank investment portfolio has remarkable influences on this. For instance, when the investment portfolio of banks comprises mainly short term securities, more of short term funds are therefore released to the economy and such do not support long term investment needed for economic development and growth.

Economic growth is a qualitative measure of increase in the productive capacity of the economy within a given period of time. It could be measured in terms of output of the economy such as Gross Domestic Product. Economic growth is a process in which a country's real national income increases over a long period of time. It is also concerned with the achievement of higher level of per capita income by poor countries and improved conditions of living for people. In the technical sense, economic development refers to a process of economic growth within an economy. Rostow (1960) described the preconditions necessary for a country to move from low level of development to a level of sustained industrialization and growth. Economic growth requires adequate stock and allocation of capital to the various sectors of the economy. These resources are needed to strengthen the operational capacity of entrepreneurs, firms and provision of infrastructure to encourage private sector investments, initiatives and growth. Banks are expected to play significant role in this process through their investment practices and portfolios.

\subsection{Theoretical Framework}

Investors focused on assessing the risks and rewards of individual securities in constructing their portfolios. A rational investor should identify those securities that offer the best opportunities for gain or reward with the least risk and then construct portfolios from them. In order to build a portfolio model, researchers and investors had to develop some theories to guide them. A good number of these theories evolved over time. On a general note, the theories of portfolio management from the General Theory, the Markowitz Theory and Arbitrage Pricing Theory attempt to examine risk, return and portfolio managers' efforts to diversify and structure their portfolio of assets to minimize risk and optimize returns.

However, in the case of investment portfolio of banks as obtained in this work, two important theories are considered. These are the Shiftability Theory and Profit Maximization Theory.

\subsubsection{Shiftability Theory}

The Shiftability theory is concerned with banks investment in marketable securities and loans with a high degree of transferability and convertibility. Hence, in contrast to the real bill doctrine, which emphasized maturity, the shiftability theory looks at the degree of shiftability or marketability of loans and investment which provide the liquidity base for bank operations (Nwankwo, 1991).

As observed by Okereke (2003), shift ability theory assumes a normal liquidity regime, which is not always the case in real life. Therefore, during liquidity crises, it becomes difficult to adopt the theory. If for instance, all the banks are eager to sell their securities at the same time, it means that no bank will buy. It follows that the marketability of the assets upon which this theory is based becomes unattainable, thereby negating the liquidity objective of the bank.

\subsubsection{Profit Maximization Theory}

Under this theory, commercial banks are viewed as rational economic units whose goal is to maximize profit. They hold portfolio of assets and given the characteristics and distributions of liabilities, they are assumed to attempt to structure their portfolio of assets in such a way as to yield the greatest return subject to these constraints.

In the profit maximization theory of the bank portfolio management, it is assumed that given such things as present and expected levels of interest rates, loan demands, cash demands, the level of discount rate, rate of returns on the various assets, among others, the banks have some desired distribution of assets in their portfolio. If the existing distribution of assets held by the banks is not the distribution desired, it is expected that they will attempt to adjust the portfolio of assets by increasing their holdings of some assets and decreasing holdings of other assets (Oluyemi, 1995). 


\subsection{Empirical Review}

There is a wide range of literature on bank portfolio investment and economic growth. For instance, Akani, Lucky and Anyamoabi (2016) examine the effect of banking sector development on Nigerian capital formation. The objective was to investigate the extent to which various banking sector reforms affect Nigerian capital formation. The desk research design was used and time series data collected from Central Bank of Nigeria (CBN) statistical bulletin from 1980 to 2014. It was discovered from the study that there is a strong correlation between banking sector reforms, development and economic growth. The reforms and development stated here had significant influence on investment portfolio of the financial institutions. These findings were consistent with the findings of a similar study carried out by Akani, Lucky and Kingsley (2016) on the relationship between Nigeria's financial sector development and macroeconomic stability from $1980-2014$.

In the same vein, Orabi (2012) made an assessment of investment portfolios of banks in Jordan. Using the historical and library research designs, it was discovered that banks in Jordan adhere to the theories of investment portfolios in terms of diversification and trade of between return and risk while complying with monetary policy regulations to ensure stability of the system and profitability. In this sense, it was established that banks play important role in the economic life of the nation. The author therefore linked economic growth of that country with the soundness of the banking system.

In a similar investigation, Ubom (2014) examined the link between investment portfolio of insurance firms and the variables of economic development such as the growth rate of gross domestic product (GDP), unemployment, capacity utilization and inflation rates in Nigeria from 1990 to 2011. Blends of desk, exploratory and descriptive research design were used. Data were analyzed using descriptive and inferential tools. The discoveries were that insurance companies in Nigeria got over $95 \%$ of income on yearly basis from premium and accumulated large sum of funds after expenditures on claims but invest less than $1 \%$ of such funds. Stock and bonds, government securities as well as real estate properties and mortgages dominated the investment portfolio of these financial institutions with heavy concentration in the assets of quoted companies. Hence, small and medium scale enterprises were not funded.

\section{RESEARCH METHODOLOGY}

\subsection{Research Design}

In this study, the desk research design was used. Hence, the data used were secondary data obtained from existing documents and sources including the Central Bank of Nigeria publications, Annual Reports of the National Bureau of Statistics, World Bank reports, as well as the internet. The data were time series and cross sectional. The method used in collecting the data was the intensive library search.

\subsection{Research Hypothesis}

The following hypotheses were formulated:

i. There is no significant relationship between gross domestic product, bank investment in treasury bill, bank investment in corporate bonds and bank investment in shares in Nigeria from 1985 to 2015.

ii. There is no relationship between unemployment rate, bank investment in treasury bills, bank investment in corporate bonds and bank investment in shares in Nigeria from 1985 to 2015.

iii. There is no significant relationship between per capita income, bank investment in treasury bill, bank investment in bonds and bank investment in shares in Nigeria from 198 to 2015.

\subsection{Variable Identification and Model Specification}

The variables incorporated into this study were the variables of investment portfolio of banks, which includes bank investment in treasury bills (BITb), bank investment in bond (BIb) and bank investment in shares (BIs) and those of economic growth in Nigeria from 1985 to 2015. The indices of economic growth in this work were the gross domestic product (GDP), unemployment rate (UNR) and per capita income (PCI). The variables of economic growth as listed here were the dependent variables while the variables of investment portfolio of banks were the independent variables. 
Based on these and the hypotheses stated in section 3.2 above, the following models were specified:

i. $\quad G D P=f(B I T b, B I b, B I s)$

$$
\begin{gathered}
G D P=c+b_{1} B I T b+b_{2} B I b+b_{3} B I s \\
G D P=c+b_{1} B I T b+b_{2} B I b+b_{3} B I s+e
\end{gathered}
$$

Where:

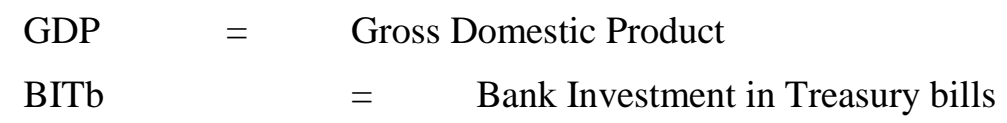

$\begin{array}{lll}\text { BIb } & = & \text { Bank Investment in bonds } \\ \text { BIs } & = & \text { Bank Investment in shares } \\ \mathrm{c}= & \text { Constant } \\ b_{1}-b_{3} & =\quad \text { Coefficient of the independent variables } \\ \mathrm{e}= & \text { error term }\end{array}$

ii. $\quad U N R=f(B I T b, B I b, B I s)$

$$
\begin{gathered}
U N R=c+b_{1} B I T b+b_{2} B I b+b_{3} B I s \\
U N R=c+b_{1} B I T b+b_{2} B I b+b_{3} B I s+e
\end{gathered}
$$

Where:

UNR = Unemployment Rate

The other variables are as defined earlier.

iii. $\quad P C I=f(B I T b, B I b, B I s)$

$$
\begin{gathered}
P C I=c+b_{1} B I T b+b_{2} B I b+b_{3} B I s \\
P C I=c+b_{1} B I T b+b_{2} B I b+b_{3} B I s+e
\end{gathered}
$$

Where:

PCI $=$ Per Capita Income

The other variables are as defined earlier.

In addition to the above model, the Augmented Dickey Fuller (ADF) test model specified as follows:

$\Delta y_{t}=\alpha+\beta_{t}+\gamma y_{t-1}+\varepsilon_{t}$, and $y$ represents the vector of the regression variables

\subsection{Method of Data Analysis}

The method of data analysis used in this study was the descriptive and inferential statistics with predominant reliance on multiple regression statistics. However, some diagnostic tests were carried out using the unit root test and co integration models as presented in section 4.0 below.

\section{RESULTS AND DISCUSSION}

\subsection{Data Presentation}

As stated earlier in the introductory part of this article, the main objectives were to examine the structure and trend of investment portfolio of banks and to establish the relationship that exist between investment portfolio of banks and economic growth in Nigeria from 1985 to 2015. The variables of investment portfolio of bank include bank investment in treasury bills, bonds, and shares, among others. Economic growth indices examined were gross domestic product (GDP), unemployment rate (UNR) and per capita income (PCI). Data on these variables were presented in tables 4.1 and 4.2 in appendix 1

\subsection{Diagnostic Analysis}

In order to test for stationarity, stability and causality, the unit root test, and co-integration test were carried out as shown below. 


\section{a. Unit Root Test}

This test follows the Augmented Dickey Fuller (ADF) test of the form:

$$
\Delta y_{t}=\alpha+\beta_{t}+\gamma y_{t-1}+\varepsilon_{t}
$$

Where $y$ represents the vector of the regression variables:

Summary of the Output from Adf Unit Root Test

\begin{tabular}{|l|l|l|l|l|l|l|}
\hline Variable & Lag Length & Critical value at 5\% & ADF & \multicolumn{4}{l|}{ Test Equation } \\
\cline { 5 - 7 } & & & Statistic & $\mathbf{R}^{2}$ & S.E & Durbin Watson \\
\hline GDP & 1 & -3.5731 & -0.996 & 0.67 & 856.81 & 1.90 \\
\hline BITb & 1 & -3.5731 & -1.8968 & 0.24 & 211.68 & 1.70 \\
\hline UNR & 0 & -3.5731 & -2.647 & 0.229 & 4.24 & 2.06 \\
\hline PCI & 1 & -3.5731 & -1.8160 & 0.2416 & 13293.41 & 1.99 \\
\hline BIb & 2 & -3.6330 & -0.8539 & 0.176 & 21.269 & 1.90 \\
\hline BIs & 2 & -3.6330 & -1.9392 & 0.64 & 292.88 & 2.03 \\
\hline BINV & 0 & -3.5731 & -3.748 & 0.652 & 186.73 & 1.55 \\
\hline CAP & 0 & -3.5731 & -1.4002 & 0.284 & 634.46 & 2.06 \\
\hline MPR & 0 & -3.5731 & -3.253 & 036 & 3.166 & 2.06 \\
\hline DEP & 0 & -3.5731 & 0.1338 & 0.556 & 571.779 & 1.95 \\
\hline SHF & 1 & -3.5731 & -1.9139 & 0.232 & 541.88 & 2.05 \\
\hline
\end{tabular}

Apart from the variables stated in the models in 3.3 above, it became imperative to consider other variables such as capital base (CAP), monetary policy rate (MPR), deposit volume (DEP) and shareholders' funds (SHF) as the factors which influence investment portfolio of banks in Nigeria. These other variables were therefore incorporated in the diagnosis.

The null hypothesis for each of the regression variables shows the existence of unit root. At $95 \%$ confidence level and using the critical values of the ADF, it is observed that:

i. The independent variables; BITb, BIb, BIs, CAP, MPR, DEP and SHF are non-stationary since their absolute value of the ADF statistic is less than the critical value. Hence, these variables have unit root problems.

ii. The dependent variable GDP, UNR and PCI also have unit root problems and hence their series are non-stationary.

iii. Only BINV has no unit root problem, and hence their series are stationary.

\section{b. Co integration Test}

Johansen Co integration Test was used to assess whether the regression variables co integrated, stationary and deterministic. This is to establish the usefulness of the models for long-term predictions. Based on the regression results, the series indicate moderate co integration which implies that the regression results are acceptable and can be used in long-run predictions.

The results show that GDP, BIs, BIb and BITb are co integrated. Also, UNR, BIs, BIb and BITb are also co integrated. At the same time, PCI, BIs, BIb and BITb are co integrated, while BINV, CAP, DEP, MPR and SHF are likewise co integrated.

\subsection{Test of Hypothesis}

\section{Hypothesis I}

\section{Regression Result I:}

$\mathrm{GDP}=\mathrm{f}(\mathrm{BITb}, \mathrm{BIb}, \mathrm{BIs})$

Using the regression results in appendix 2.1, the multiple regression equation is given as:

$\mathrm{GDP}=22251.50+25.12 \mathrm{BITb}+113.70 \mathrm{BIb}-6.69 \mathrm{BIs}$

This indicates that the gross domestic product (GDP) increases by an average of $\$ 22$. 251billion, when $\mathrm{BITb}=\mathrm{BIb}=\mathrm{BIs}=0$. Furthermore, a N1billion increase in bank investments in treasury bills 
(BITb) increases GDP by $\$ 25.12$ billion, $\$ 1$ billion increase in bank investments in bonds (BIb) increases the GDP by $\$ 13$.70billion and finally, while 1 billion increase in BIS results in a decline in GDP by $\$ 6.69$ billion in the year.

The coefficient of determination $\mathrm{R}^{2}$ value of 0.8728 indicates that $87.28 \%$ of the variations in GDP have been explained by the explanatory variables (BITB, BICB and BIS). The remaining $12.72 \%$ of the variation in the response variable GDP can be attributed to other factors outside the scope of this model. Adjusted $\mathrm{R}^{2}$ value of $85.37 \%$ indicated a high predictive power of the explanatory variables to explain the variations in the GDP. This shows the goodness of fit of the model. The Durbin Watson Statistic value of 0.878 indicates the presence of serial auto correlation. This value is less than 2 , and the results of the regression are robust enough to be used as a predictor of GDP. This is confirmed by the co integration tests carried out earlier.

In testing the statistical significance of the independent of explanatory variables at 0.05 level of significance and degrees of freedom $(n-k)$, the decision rule specifies that, if the absolute value of the computed $t$-statistic is greater than the tabulated value ( $\mathrm{t}$-critical value), the hypothesis should be rejected. This is given in the table below:

\begin{tabular}{|l|l|l|l|}
\hline Variable & Computed t-statistic & t-critical value at 5\% and df=28 & Decision \\
\hline BITb & 5.276 & 1.701 & Statistically significant \\
\hline BIb & 1.793 & 1.701 & Statistically significant \\
\hline BIs & -0.976 & 1.701 & Statistically insignificant \\
\hline $\mathrm{R}^{2}$ & 0.872868 & Mean dependent var & 37499.31 \\
\hline Adjusted $\mathrm{R}^{2}$ & 0.853798 & S.D. dependent var & 16996.09 \\
\hline S.E of regression & 6498.691 & Akaike info criterion & 20.54760 \\
\hline Sum squared resid & $8.45 \mathrm{E}+08$ & Schwarz criterion & 20.74394 \\
\hline Log likelihood & -242.5712 & F-statistic & 45.77215 \\
\hline $\begin{array}{l}\text { Durbin-Watson } \\
\text { stat }\end{array}$ & 0.878584 & Prob (F-statistic) & 0.000000 \\
\hline
\end{tabular}

Source: Regression estimates

From the table above, bank investments in treasury bills and bonds have significant relationship with GDP while bank investment in shares does not have any significant relationship with GDP. In testing for the overall model, the tabulated value of $\mathrm{f}$-statistic $\left(\mathrm{f}_{27,3}\right)$ is given as 2.960 . Hence, as the computed f-statistic value of 45.772 is greater than 2.960, the hypothesis which states that there is no significant relationship between GDP, BITb, BIb and BIs is rejected. Therefore, a significant relationship exists between GDP, BITb, BIb and BIs.

\section{Hypothesis II}

\section{Regression Result II:}

$\mathrm{UNR}=\mathrm{f}(\mathrm{BITB}, \mathrm{BIB}, \mathrm{BIS})$

Using the regression result in appendix 2.2, the multiple regression equation below was obtained.

$\mathrm{UNR}=5.36+0.02 \mathrm{BITb}-0.117 \mathrm{BIb}-0.008 \mathrm{BIs}$

This model indicates that unemployment rate increases by $5.36 \%$ on average when $\mathrm{BITb}=\mathrm{BIb}=\mathrm{BIs}$ $=0$. A $1 \%$ increase in bank investment in treasury bills increases unemployment rate by $0.02 \%$, while the same rate of change in bank investment in bonds decreases unemployment rate by $0.117 \%$. Similarly, $1 \%$ increase in bank investment in shares leads to a decrease of $0.0078 \%$ in unemployment rate.

The $\mathrm{R}^{2}$ value of 0.6888 indicates a high positive correlation between unemployment rate and the independent variables. This indicates that $68.88 \%$ of the variations in unemployment rate are explained by the explanatory variables. The remaining $31.12 \%$ of the variations is due to other variables outside this model. The adjusted $\mathrm{R}^{2}$ value of $64.2 \%$ shows the extent of the predictive power of the independent variables to explain variations in unemployment rate. This also indicates the goodness of fit of the model. The Durbin Watson value of 1.31 is less than 2 using the rule of thumb; hence, there is positive auto correlation. 
In testing the statistical significance of the variables, the computed t-statistic of the independent variables is measured against the tabulated t-statistic value of $1.700\left(\mathrm{t}_{0.05,28}\right)$. This is shown in the table below:

\begin{tabular}{|l|l|l|l|}
\hline Variable & Computed t-statistic & t-critical value $\left.\mathbf{( t}_{\mathbf{0 . 0 5}, \mathbf{2 8}}\right)$ & Decision \\
\hline BITb & 6.276 & 1.701 & Statistically significant \\
\hline BIb & -2.644 & 1.701 & Statistically significant \\
\hline BIs & -1.638 & 1.701 & Statistically insignificant \\
\hline $\mathrm{R}^{2}$ & 0.688781 & Mean dependent var & 12.20833 \\
\hline Adjusted R & 0.642098 & S.D. dependent var & 7.555183 \\
\hline S.E of regression & 4.519880 & Akaike info criterion & 6.005860 \\
\hline Sum squared resid & 408.5864 & Schwarz criterion & 6.202202 \\
\hline Log likelihood & -68.07032 & F-statistic & 14.75448 \\
\hline Durbin-Watson stat & 1.319547 & Prob (F-statistic) & 0.000027 \\
\hline
\end{tabular}

Source: Regression estimates

The above table shows that BITb has the most statistically significant relationship with unemployment rate with a computed t-statistic of 6.276 , followed by BIb. However, BIS has an insignificant relationship with unemployment rate as indicated by the absolute value of 1.638 compared with the critical value of 1.701. Finally, as the computed f-statistic value of 14.754 is greater than the tabulated value of F-statistic at 2.960 , the hypothesis was rejected, implying that there is a significant relationship between unemployment rate and BITb, BIb and BIs.

\section{Hypothesis III}

\section{Regression Result III:}

$\mathrm{PCI}=\mathrm{f}(\mathrm{BITb}, \mathrm{BIb}, \mathrm{BIs})$

Using the regression results obtained for hypothesis III, (see appendix 2.3), the multiple regression equation below was obtained.

$\mathrm{PCI}=196587.6+120.90 \mathrm{BITb}+253.09 \mathrm{BIb}-21.83 \mathrm{BIs}$

The model indicates the average value of per capita income (PCI) of $\$ 196.587$ billion when BITb = $\mathrm{BIb}=\mathrm{BIs}=0$. $\mathrm{A} \$ 1.00$ increase in bank investment in treasury bills (BITb) increases PCI by $\$ 120.90$, while a $\$ 1.00$ increase in bank investment in bonds (BIb) increases PCI by $\$ 253.09$. In contrast, a $\$ 1$ increase in bank investment in shares reduces PCI by $\$ 21.83$.

The $\mathrm{R}^{2}$ value of 0.7900 indicates high positive correlation between PCI and BITb, BIb and BIs. The adjusted $\mathrm{R}^{2}$ value of 0.7585 shows that $75.86 \%$ of the variations in PCI is explained by the explanatory variables. The remaining $24.15 \%$ of the variations can be attributed to other variables not considered in this study. This also indicates a high predictive power of the independent variables to account for the changes that occur in PCI. This shows the goodness of fit of the model. The Durbin Watson statistic value of 0.66 indicates the presence of serial correlation and the regression results are acceptable.

In testing the statistical significance of the independent variables, the table below was used

\begin{tabular}{|l|l|l|l|}
\hline Variable & Computed t-statistic & t-critical value $\left.\mathbf{( t}_{\mathbf{0 . 0 5}} \mathbf{2 8}\right)$ & Decision \\
\hline BITb & 4.393 & 1.701 & Statistically significant \\
\hline BIb & 0.690 & 1.701 & Statistically insignificant \\
\hline BIs & -0.550 & 1.701 & Statistically insignificant \\
\hline $\mathrm{R}^{2}$ & 0.790033 & Mean dependent var & 264157.6 \\
\hline Adjusted $\mathrm{R}^{2}$ & 0.758538 & S.D. dependent var & 76453.39 \\
\hline S.E of regression & 37568.23 & Akaike info criterion & 24.05672 \\
\hline Sum squared resid & $2.82 \mathrm{E}+10$ & Schwarz criterion & 24.25306 \\
\hline Log likelihood & -284.6806 & F-statistic & 25.08441 \\
\hline Durbin-Watson stat & 0.656866 & Prob (F-statistic) & 0.000001 \\
\hline
\end{tabular}

Source: Regression estimates 
The above table indicates that only bank investments in treasury bills show significant relationship with PCI with a computed t-value of 4.393 which is greater than 1.701. As the computed f-statistic value of 25.0844 is greater than the critical value of $2.960\left(\mathrm{f}_{27,3}\right)$, the hypothesis which states that there is no significant relationship between PCI and BITb, BIb and BIs was rejected. The implication here is that per capita income as a measure of economic growth in Nigeria is influenced by the investment portfolio of banks.

\section{CONCLUSION AND RECOMMENDATIONS}

\subsection{Conclusion}

This study was carried out to examine the relationship between investment portfolio of banks and economic growth in Nigeria noting the role of these financial institutions as economic development agents. The variables of economic growth examined here were those of the gross domestic product (GDP), unemployment rate and per capita income. On the other hand, the variables of investment portfolio of banks captured in the study include bank investment in treasury bills, bonds and shares. The structure of the investment portfolio of these financial intermediaries was discovered to be dominated by short term assets which could not promote long term investments needed to enhance economic growth.

However, based on the various test and the findings thereof, it was established that there is a significant relationship between gross domestic product (GDP), unemployment rate, per capita income and investment portfolio of banks in Nigeria. The investment portfolio of banks as stated earlier is proxied by the values of the bank investment in the various assets including treasury bills, bonds and shares. On the whole, it became pertinent to conclude that although there exist statistical significant relationship between the variables of economic growth and those of investment portfolio of banks in Nigeria, the real situation in the country is rather that of marginal and/or insignificant relationship. This is in view of the fact that even when there is an observed continuous increment in the total investment portfolio of banks, the level of economic growth in the country is rather abysmal.

\subsection{Recommendations}

From the conclusions above, the following recommendations were made:

i. Bank should restructure their investment portfolio with focus on long term securities to ensure increase in the maturity and the volume of funds made available to the borrower through such investments.

ii. The various investment portfolio adjustments by banks in reaction to monetary policy changes and interest rate movements in the country should be properly managed, timed and harnessed with the bank policies and objectives and economic growth aspiration and direction of the government.

iii. Above all, more researches should be carried out on the analysis of investment portfolio of banks and its implications on economic growth in a recessed economy such as Nigeria.

\section{REFERENCES}

[1] Akani, H. W., Lucky, A. L., \& Uzah, C. K., (2016): Financial Sector Development and Macroeconomic Stability in Nigeria: A Long -Run Analysis. International Journal of Empirical Finance, Vol.5, No.2, Pp. $112-128$.

[2] Akani, H. W., \& Momodu, A. A., (2016): Empirical Analysis of Financial Sector Development and National Savings: Evidence from Nigeria Economy. International Journal of Financial Economics, Vol. 5, No. 1, Pp. 46-60.

[3] Anyanwu, C.A. (2010): An overview of current banking sector reforms and the real sector of the Nigerian economy. CBN Economic and Financial Review, Vol. 48, No. 4, Pp. 31-57.

[4] Bukue, S. S. \& Ubom, U. B. (2013): The Import of Interest Rates for Deposit Money Banks Performance in Developing Economies: The Nigerian Experience. Journal of Finance and Business Policy, Vol. 1, No.3.

[5] Ngerebo-a, T.A \& Lucky, A.L., (2016): Interest Rate and Deposit money Banks profitability. Evidence from Nigeria (1980-2014). International Journal of Empirical finance, Vol. 5, No. 1, Pp. 22-35

[6] Nwankwo, G. O. (1991): Bank Management Principles and Practices. Lagos: Mathus Press. 
[7] Okereke, E. J. (2003): Banking in Nigeria: Practices and Management. Owerri: Jeso International Publishers.

[8] Oluyemi, S. A. (1995): Recent Development in the Nigerian Banking System and Insured Banks' Asset Portfolio Behavior: An empirical study. Nigerian Deposit Insurance Corporation Quarterly, Vol. 5, No. 4, Pp. 32-44

[9] Orabi, M.M.A., (2012): Assessment of investment portfolio of Jordan Banks. European Scientific Journal Vol. 8, No. 12, Pp. 251-271

[10] Ubom, U. B. (2009): Economic Absorption and the Contributions of Banks to Economic Development in Nigeria. Journal of Business and Finance. Vol. 2, No. 1, Pp. 229 -241.

[11] Ubom, U. B. (2010): Risk, Risk Management and the Growth of Business. Journal of Contemporary African Business. Vol. 1, No. 1, Pp. 69 -84

[12] Ubom, U.B., (2014): Investment Portfolio of insurance firms and Economic Development in Nigeria. International Journal of Finance and Accounting Vol. 3, No. 5, Pp. 268-294.

[13] Ubom, Michael and Essien (2016): Bank Portfolio Structure and Absorption Theory of Economic Development: A Theoretical Proposition. Expert Journal of Finance. Vol. 4, Pp. $44-51$.

\section{APPENDIX 1}

Table4.1. Profile of Investment Portfolio of Banks and Economic Growth Indices in Nigeria, 1985 to 2015

\begin{tabular}{|c|c|c|c|c|}
\hline Year & $\operatorname{BINV}(\mathbb{A}, \mathrm{B})$ & 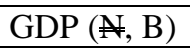 & UNR $(\%)$ & PCI $(N, B)$ \\
\hline 1985 & 8 & 14953.91 & 6.1 & 223088.3 \\
\hline 1986 & 3.1 & 15237.99 & 5.3 & 198319.6 \\
\hline 1987 & 5.3 & 15263.93 & 7.0 & 172402.7 \\
\hline 1988 & 5.3 & 16215.37 & 5.1 & 180584.5 \\
\hline 1989 & 2.5 & 17294.68 & 4.5 & 187298.5 \\
\hline 1990 & 7.7 & 19305.63 & 3.5 & 205824.7 \\
\hline 1991 & 6.3 & 19199.06 & 3.1 & 199405.9 \\
\hline 1992 & 6.0 & 19620.19 & 3.5 & 195279.5 \\
\hline 1993 & 29.6 & 19927.99 & 3.4 & 194427.8 \\
\hline 1994 & 9.5 & 19979.12 & 3.2 & 191358.2 \\
\hline 1995 & 18.7 & 20353.2 & 1.9 & 186069 \\
\hline 1996 & 47.5 & 21177.92 & 2.8 & 190545.7 \\
\hline 1997 & 39.6 & 21789.1 & 3.4 & 191055.2 \\
\hline 1998 & 42.8 & 22332.87 & 3.5 & 191397.7 \\
\hline 1999 & 189 & 22449.41 & 17.5 & 187546.1 \\
\hline 2000 & 279.6 & 23688.28 & 13.1 & 192616.4 \\
\hline 2001 & 207.4 & 25267.54 & 13.6 & 1996104.4 \\
\hline 2002 & 476.9 & 28957.71 & 12.6 & 198437.8 \\
\hline 2003 & 471 & 31709.45 & 14.8 & 213475.7 \\
\hline 2004 & 643.3 & 35020.55 & 13.4 & 278249 \\
\hline 2005 & 644.7 & 37474.95 & 11.9 & 280457.1 \\
\hline 2006 & 504.4 & 39995.5 & 12.3 & 295636.1 \\
\hline 2007 & 527 & 42922.41 & 12.7 & 307593.6 \\
\hline 2008 & 328.5 & 46012.52 & 14.9 & 318307.7 \\
\hline 2009 & 1225 & 49856.1 & 19.7 & 331407.7 \\
\hline 2010 & 1467.9 & 54612.26 & 21.1 & 347934.4 \\
\hline 2011 & 1888.3 & 57511.04 & 23.9 & 355255 \\
\hline 2012 & 1753.4 & 59929.89 & 27.4 & 360615.2 \\
\hline 2013 & 1647.7 & 63218.72 & 24.7 & 370004.2 \\
\hline 2014 & 3476.58 & 676152.79 & 7.8 & 383023.4 \\
\hline 2015 & 1508.73 & 69023.93 & 9.9 & 382985.4 \\
\hline
\end{tabular}

Source: CBN Statistical Bulletin for the various years

Table4.2. Breakdown of Investment Portfolio of Banks in Nigeria from 1985 to 2015

\begin{tabular}{|c|c|c|c|c|}
\hline Year & $\operatorname{BITb}(\nexists, B)$ & $\mathrm{BIb}(\mathbb{N}, \mathrm{B})$ & BIs $(\mathbb{A}, \mathrm{B})$ & 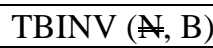 \\
\hline 1985 & 8 & NA & NA & 8 \\
\hline 1986 & 3.1 & NA & NA & 3.1 \\
\hline 1987 & 5.3 & NA & NA & 5.3 \\
\hline 1988 & 5.3 & NA & NA & 5.3 \\
\hline
\end{tabular}


Investment Portfolio of Banks and Economic Growth in Nigeria: A Review from 1985 to 2015

\begin{tabular}{|c|c|c|c|c|}
\hline 1989 & 2.5 & NA & NA & 2.5 \\
\hline 1990 & 7.7 & NA & NA & 7.7 \\
\hline 1991 & 6.3 & NA & $\mathrm{NA}$ & 6.3 \\
\hline 1992 & 5.2 & 0.3 & 0.5 & 6.0 \\
\hline 1993 & 28.9 & 0.6 & 0.1 & 29.6 \\
\hline 1994 & 8.6 & 0.3 & 0.6 & 9.5 \\
\hline 1995 & 17.7 & 0.4 & 0.6 & 18.7 \\
\hline 1996 & 46.8 & 0.2 & 0.5 & 47.5 \\
\hline 1997 & 38.1 & 0.9 & 0.6 & 39.6 \\
\hline 1998 & 40.8 & 0.9 & 1.1 & 42.8 \\
\hline 1999 & 186.1 & 0.1 & 2.8 & 189 \\
\hline 2000 & 275.8 & 1.1 & 2.7 & 279.6 \\
\hline 2001 & 199.3 & 1.5 & 6.6 & 207.4 \\
\hline 2002 & 460.2 & 5.8 & 10.9 & 476.9 \\
\hline 2003 & 430.8 & 15.1 & 25.1 & 471 \\
\hline 2004 & 595.8 & 13.2 & 34.3 & 643.3 \\
\hline 2005 & 585 & 17 & 42.7 & 644.7 \\
\hline 2006 & 499 & 2.7 & 2.7 & 504.4 \\
\hline 2007 & 525.8 & 0.6 & 0.6 & 527 \\
\hline 2008 & 325.9 & 1.3 & 1.3 & 328.5 \\
\hline 2009 & 585.4 & 27.6 & 612 & 1225 \\
\hline 2010 & 925.3 & 56.6 & 486 & 1467.9 \\
\hline 2011 & 1458.3 & 74.8 & 355.2 & 1888.3 \\
\hline 2012 & 1419.6 & 46.7 & 287.1 & 1753.4 \\
\hline 2013 & 1317.9 & 55.8 & 274 & 1647.7 \\
\hline 2014 & 1822.3 & 143.98 & 1510.3 & 3476.58 \\
\hline 2015 & 1045.35 & 147.23 & 316.15 & 1508.73 \\
\hline
\end{tabular}

Source: CBN Statistical Bulletin for the various years

\section{APPENDIX 2}

\section{Appendix 2.1}

\section{Regression Result 1}

Dependent Variable: GDP

Method: Least Squares

Date: 07/23/17 Time: 12:43

Sample(adjusted): 19922015

Included observations: 24 after adjusting endpoints

\begin{tabular}{|l|l|l|l|l|}
\hline Variable & Coefficient & Std. Error & t-Statistic & Prob. \\
\hline C & 22251.50 & 2015.248 & 11.04157 & 0.0000 \\
\hline BITB & 25.12278 & 4.761242 & 5.276517 & 0.0000 \\
\hline BICB & 113.7041 & 63.40289 & 1.793358 & 0.0881 \\
\hline BIS & -6.698612 & 6.863813 & -0.975932 & 0.3408 \\
\hline R-squared & 0.872868 & Mean dependent var & 37499.31 \\
\hline Adjusted R-squared & 0.853798 & S.D. dependent var & 16996.09 \\
\hline S.E. of regression & 6498.691 & Akaike info criterion & 20.54760 \\
\hline Sum squared resid & $8.45 E+08$ & Schwarz criterion & 20.74394 \\
\hline Log likelihood & -242.5712 & F-statistic & 45.77215 \\
\hline Durbin-Watson stat & 0.878584 & Prob(F-statistic) & 0.000000 \\
\hline
\end{tabular}

\section{Appendix 2.2}

\section{Regression Result 2}

Dependent Variable: UNR

Method: Least Squares

Date: 07/23/17 Time: 12:45

Sample(adjusted): 19922015

Included observations: 24 after adjusting endpoints

\begin{tabular}{|l|l|l|l|l}
\hline Variable & Coefficient & Std. Error & t-Statistic & Prob.
\end{tabular} 
Investment Portfolio of Banks and Economic Growth in Nigeria: A Review from 1985 to 2015

\begin{tabular}{|l|l|l|l|l|}
\hline C & 5.367063 & 1.401618 & 3.829191 & 0.0010 \\
\hline BITB & 0.020784 & 0.003311 & 6.276405 & 0.0000 \\
\hline BICB & -0.116605 & 0.044097 & -2.644274 & 0.0156 \\
\hline BIS & -0.007820 & 0.004774 & -1.638190 & 0.1170 \\
\hline R-squared & 0.688781 & Mean dependent var & 12.20833 \\
\hline Adjusted R-squared & 0.642098 & S.D. dependent var & 7.555183 \\
\hline S.E. of regression & 4.519880 & Akaike info criterion & 6.005860 \\
\hline Sum squared resid & 408.5864 & Schwarz criterion & 6.202202 \\
\hline Log likelihood & -68.07032 & F-statistic & 14.75448 \\
\hline Durbin-Watson stat & 1.319547 & Prob(F-statistic) & 0.000027 \\
\hline
\end{tabular}

Appendix 2.3

\section{Regression Result 3}

\begin{tabular}{|c|c|c|c|c|}
\hline \multicolumn{5}{|c|}{ Dependent Variable: PCI } \\
\hline \multicolumn{5}{|c|}{ Method: Least Squares } \\
\hline \multicolumn{5}{|c|}{ Sample(adjusted): 1992 2015 } \\
\hline \multicolumn{5}{|c|}{ Included observations: 24 after adjusting endpoints } \\
\hline Coefficient & Std. Error & t-Statistic & Prob. \\
\hline Variable & 196587.6 & 11649.93 & 16.87457 & 0.0000 \\
\hline C & 120.9049 & 27.52423 & 4.392671 & 0.0003 \\
\hline BITB & 253.0940 & 366.5253 & 0.690523 & 0.4978 \\
\hline BICB & -21.83849 & 39.67896 & -0.550380 & 0.5882 \\
\hline BIS & 0.790033 & Mean dependent var & 264157.6 \\
\hline R-squared & 0.758538 & S.D. dependent var & 76453.39 \\
\hline Adjusted R-squared & 37568.23 & Akaike info criterion & 24.05672 \\
\hline S.E. of regression & $2.82 \mathrm{E}+10$ & Schwarz criterion & 24.25306 \\
\hline Sum squared resid & -284.6806 & F-statistic & 25.08441 \\
\hline Log likelihood & 0.656866 & \multicolumn{3}{c|}{ Prob(F-statistic) } \\
\hline Durbin-Watson stat & \multicolumn{3}{c}{0.000001} \\
\hline
\end{tabular}

Citation: U B. Ubom, and S. O. Akpan. "Investment Portfolio of Banks and Economic Growth in Nigeria: A Review from 1985 to 2015." International Journal of Managerial Studies and Research (IJMSR), vol 5, no. 10, 2017, pp. 9-21. doi: http://dx.doi.org/10.20431/2349-0349.0510002.

Copyright: (C) 2017 Authors. This is an open-access article distributed under the terms of the Creative Commons Attribution License, which permits unrestricted use, distribution, and reproduction in any medium, provided the original author and source are credited. 